\begin{tabular}{ll} 
ROBERT KOCH INSTITUT \\
\hline KO MPA KT Facts and Trends from Federal Health Reporting \\
\hline
\end{tabular}

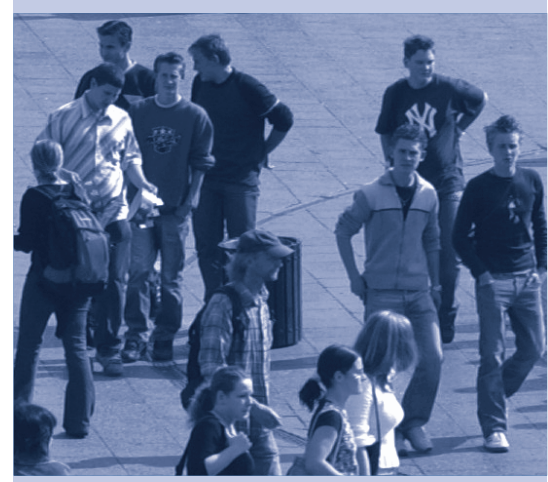

Key messages

- The unemployed are more frequently ill and die earlier.

- The unemployed and people in precarious work have more health problems.

- Mental health in particular is impaired by unemployment and precarious work.

- Illnesses can be both the consequence and the cause of unemployment.

Volume 3, no. 1, 2012

\section{Unemployment, precarious work and health}

In 2011 the unemployment rate in Germany stood at 7.1 percent - lower than at any other time since the country's reunification. The fewer people are unemployed, the more this group risks disappearing from public awareness. From the perspective of the health sciences, however, unemployment and its individual consequences should remain a key topic for the fields of research and health promotion.

Many studies have shown that the unemployed in Germany are not as healthy as people in employment (Berth et al. 2008, Brenner 2006, Elkeles 1999, Hanisch 1999, Lampert et al. 2011, RKI 2003, Weber et al. 2007). As a rule, becoming unemployed has considerable effects on the lifestyle of the people affected. They lose a significant proportion of their income and are obliged to comply with the rules of the employment agency. Non-material losses can also have a serious effect, e.g. the loss of a fixed daily routine and other time structures, or the loss of contact with colleagues at the workplace (Brief et al. 1995, Creed, Macintyre 2001, Fryer 1986, Jahoda 1983, Janlert, Hammarstrom 2009, Warr 1987).

Moreover, the social prestige that is associated with a career declines, the longer the period of unemployment lasts. The pressures exerted by unemployment can generate psychosocial stress, encourage health-threatening behaviour and promote the incidence of illnesses. For example, it has been well documented that mental illnesses in particular - such as depression and anxiety - are more frequent among the unemployed (Hollederer 2003, RKI 2003). In addition, people in work who have chronic health problems have a higher risk of becoming unemployed, while unemployed people with health problems have a slimmer chance of finding work again (Arrow 1996, Voss et al. 2004, Weber et al. 2007).

As a consequence, social and health problems often accumulate for the long-term unemployed. This mechanism is of particular significance in times of economic recovery, when the long-term unemployed with health problems are frequently unable to find work despite favourable economic conditions. As a result, the subjective effect of unemployment on those affected is a particularly heavy burden during periods of growth (Novo et al. 2001, Scanlan, Bundy 2009). Avoiding the negative health consequences of unemployment is therefore an important task for prevention and health promotion in Germany and can help improve the unemployed's chances of re-employment.

Alongside unemployment, the threat to secure employment has also moved into the focus of public attention. Despite the progress of the German labour market in recent years, the proportion of non-regular employment contracts has risen considerably (Bispinck, Schulten 2011). More and more people in Germany are employed in what are known as »precarious jobs« - defined as non-permanent jobs which are not subject to social insurance contributions or are regarded as endangered (Ferrie 2006). Men and women in precarious work often have temporary 
contracts or work for temporary employment agencies - or for very low wages. These tendencies are also relevant for health research, since not only unemployment itself, but also the subjective threat of job insecurity can cause psychosocial stress (Dragano, Siegrist 2006, Ferrie 2006, Zok 2006). The results of longitudinal studies indicate that job insecurity has a negative effect on mental health, but also that the latter improves significantly once people return to secure employment (Ferrie 2006).

This issue of GBE kompakt presents topical findings on the interactions between unemployment, precarious employment and health. It draws on data from the 2010 study »German Health Update (GEDA), which was carried out by the Robert Koch Institute within the framework of health monitoring (Kurth et al. 2009). The analyses are based on information from interviews with 14,693 men and women between the ages of 18 and 64 who were either employed or unemployed at the time of the survey. The data are supplemented with selected findings from official statistics and health insurance statistics.

\section{Unemployment influences life expectancy}

The findings of several national and international studies show that the experience of unemployment is associated with a greater mortality risk among both women and men (Grobe 2006, Martikainen, Valkonen 1996, Voss et al. 2004). In general, people who have experienced unemployment have a higher mortality rate and a greater risk of dying as a result of suicide or for unknown external reasons. The current findings are interpreted in such a way that the relationship between unemployment and mortality develops via

\section{German Health Update (GEDA) \\ Data holder: \\ Objectives: \\ Survey method: \\ Population: \\ Sample: \\ Cooperation rate: \\ Survey period: \\ Robert Koch Institute \\ To provide up-to-date data on health-related issues, to analyse temporal developments and trends Computer-assisted telephone interviews (CATI) \\ Residential population of Germany aged 18 and over \\ 22,050 women und men $55.8 \%$ \\ September 2009 to Juli 2010}

a loss of social resources, rising psychosocial stress and the resultant development of anxiety- and depression-related disorders.

Figure 1 shows - at the level of all 96 planning regions (RORs) in Germany - that there is a connection between the unemployment rate and life expectancy at birth. RORs are regions within the federal states comprising several towns and rural districts. As a rule they consist of one major town as the economic centre and its rural environs. The data are received from the official regional database INKAR 2010 (BBR 2010). At the level of RORs there is a significant link between the rate of unemployment and the life expectancy of men and women. In the case of women, life expectancy falls by approximately one month for each percent point by which the unemployment rate increases. For men the corresponding figure is three months. There was a difference of 0.6 years for women and 2.4 years for men between the regions with the highest and lowest rates of unemployment.

Figure 1

Life expectancy at birth and unemployment rate in 2008 by gender Source: INKAR 2010 (BBR 2010)

86

Mean life expectancy in years

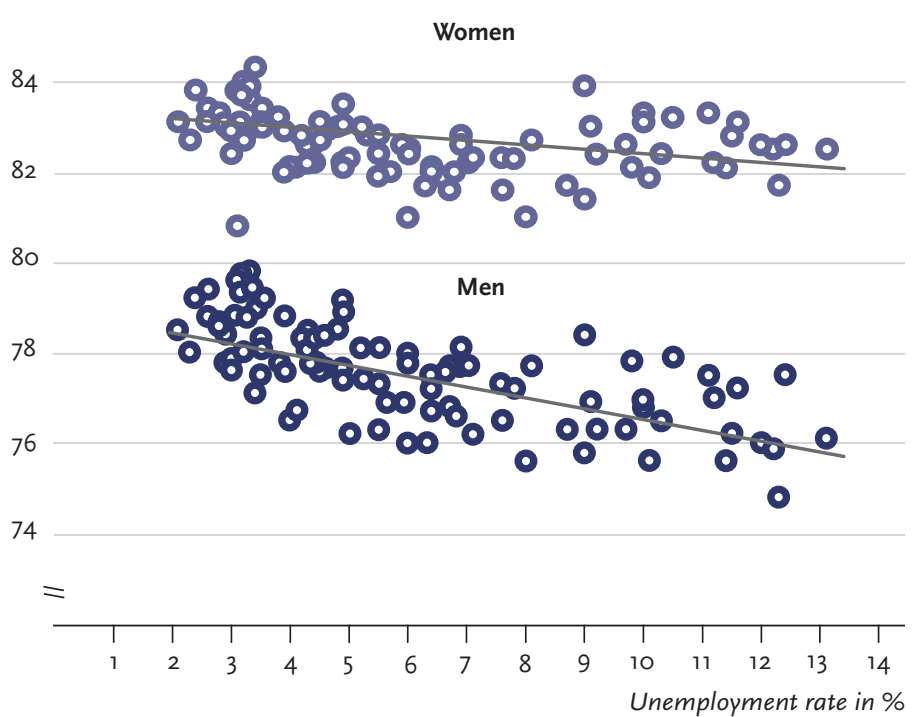


The unemployed are more frequently ill

Unemployed women and men suffer from many disorders and illnesses more frequently than employed people of the same age (RKI 2003). The relevant information here comes, for example, from the occupational disability (»days off sick «) statistics of the statutory health insurance companies. The 2010 health report of the company health insurance funds (Betriebskrankenkassen, BKK) shows that in 2009 unemployed women were much more frequently unfit for work than female employees - with an average of 22.8 compared to 12.4 days. For men the corresponding figures were 19.5 and 9.7 days.

Figure 2 shows the relation between registered days off sick among unemployed and employed women and men, differentiated according to diagnosis. It shows that the unemployed are more frequently affected by mental and behavioural disorders, nutritional and metabolic diseases as well as diseases of the musculoskeletal and the nervous system.

\section{The unemployed and people in precarious employment} have more health problems

The 2010 GEDA study records impairments of mental well-being and physical health - irrespective of whether the person concerned consulted a doctor - and the extent to which these impairments had an effect on the respective respondent's everyday activities. As confirmed by the accounting data of the health insurance companies, it becomes clear that the unemployed are more frequently
How GEDA 2010 measures unemployment and precarious employment

The assessment is based on the self-classification of respondents who were either employed or unemployed. People who were neither employed nor unemployed were excluded from the analyses $(24.1 \%$ of the women and $13.1 \%$ of the men in GEDA 2010). The concept of subjective measurement takes into account the fact that people who are not registered as unemployed might be looking for full-time or part-time employment. The respondents were divided into four groups:

1) People in full-time or part-time employment who do not believe their security of employment is at risk $(77.2 \%$ of the women and $82.8 \%$ of the men).

2) People who believe their security of employment is at risk ( $12.5 \%$ of the women and $9.7 \%$ of the men).

3) People who have been unemployed for less than 12 months (4.0\% of the women and $3.8 \%$ of the men).

4) People who have been unemployed for 12 months or longer $(6.3 \%$ of the women and $3.7 \%$ of the men).

Figure 2

Inability to work (no. of days) among the unemployed compared to employees in 2009 by gender

Data basis: BKK Gesundheitsreport 2010

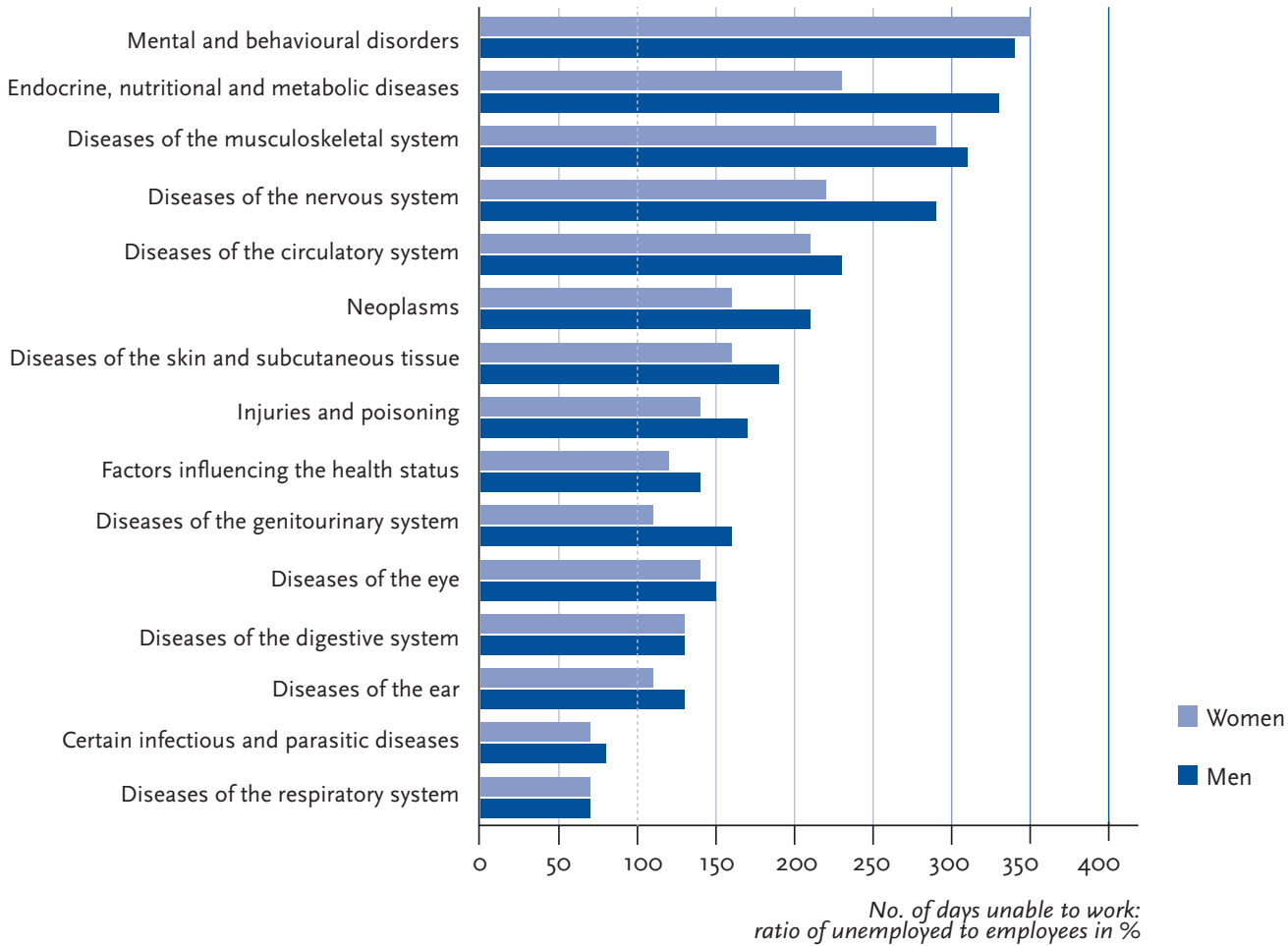


Figure 3

Days of physical and mental impairment and a resultant impairment of day-to-day activities in the last four weeks by employment status and gender

Data basis: GEDA 2010

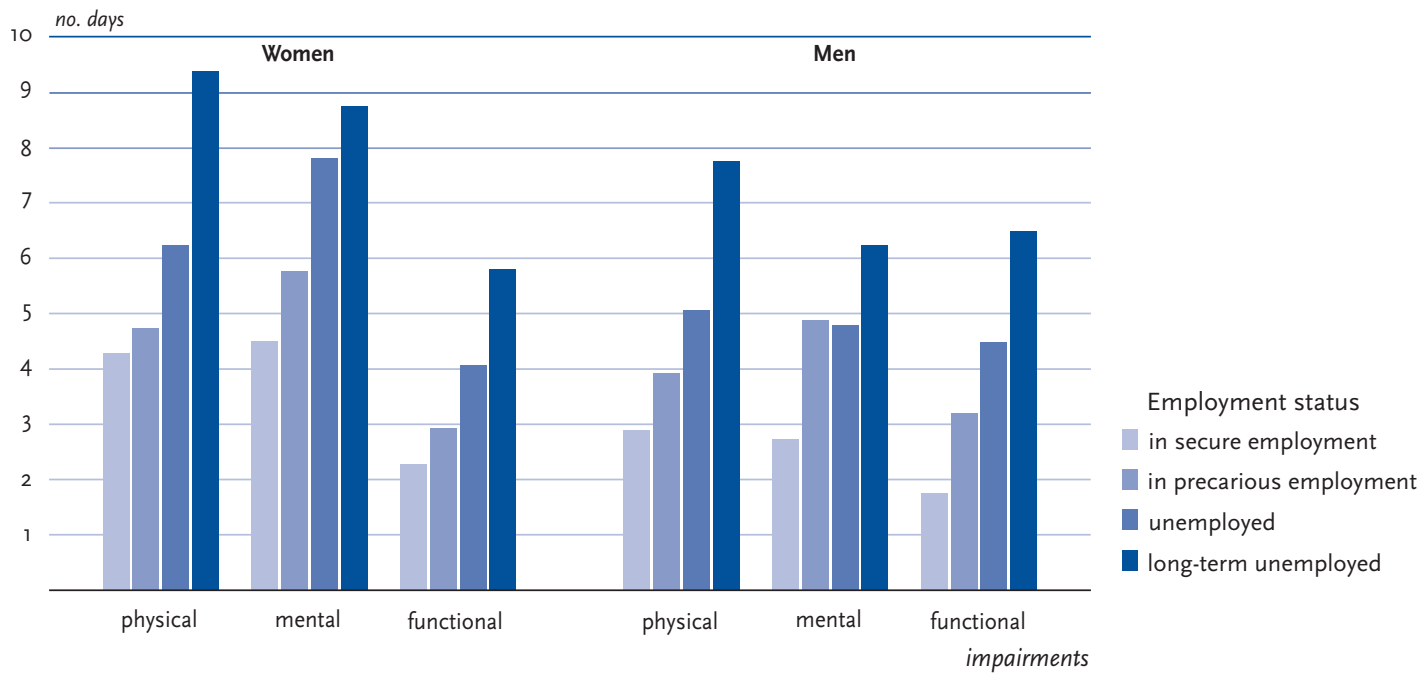

and the ability to carry out everyday activities increase successively with job insecurity and the duration of unemployment. Subsequent analyses monitored the duration of the impairments to see if there were age differences between the respondents.

Taking age differences into account, women in precarious employment report physical complaints on $35 \%$ more days than women in secure jobs. In the case of unemployed women who have been unemployed for less than one year, the number is about $63 \%$, for the long-term unemployed about $105 \%$. In men the corresponding differences from those in secure employment are $49 \%, 83 \%$ and $145 \%$ respectively. There are also comparable differences for days with mental impairment and days when everyday activities are impaired by health problems.

\section{Mental well-being is low among the unemployed}

The 2010 GEDA study 2010 covered two scales from the internationally recognized and validated questionnaire for measuring a person's health-related quality of life (SF-36) (Bellach et al. 2000, Bullinger 1995), which could provide further information on the mental health of the unemployed. The scales measure the respondents' general mental wellbeing and vitality. The reference period is the last four weeks prior to the interview.

Figure 4 shows the points scored by men and women on both scales; they are differentiated according to employment status and compared to age-specific reference values for a mentally healthy population (reference value $=50$ points). According to this analysis, mental health declines considerably as the duration of unemployment increases. The figures on the mental well-being scale for precariously employed and unemployed women and men are much lower than the age-specific reference values.
The unemployed more often exhibit behaviour patterns which constitute a health risk

Findings on health-related behaviour indicate that unemployed men and women and people threatened by unemployment behave more often in a way that constitutes a risk to their health. They also take less care of their health than those employed in secure jobs. This must be seen in the context of the considerable psychosocial burden to which the unemployed are exposed. There are differences, for example, in health awareness, sporting activities and substance consumption (Hollederer 2011, Lampert et al. 2011, RKI 2003, Schunck, Rogge 2010).

Figure 5 shows the percentage of smokers and heavy smokers among men and women according to their employment status. Despite their difficult economic situation, the unemployed smoke much more frequently and more heavily than the employed; at the same time, there are no differences between those in precarious jobs and those in secure jobs.

After taking age differences into account, the current risk of being a smoker is 1.7 times higher respectively among short-term unemployed women and long-term unemployed women than among the comparison group of securely employed women. In the case of men the corresponding risks are 2.3 times and 2.1 times higher respectively. Tobacco consumption is not significantly higher among men and women in precarious employment when age differences are taken into account.

\section{Illnesses are both a consequence and cause of unemployment}

The connection between unemployment and health is influenced by the fact that women and men with health problems, chronic illnesses and handicaps become unem- 
Figure 4

Vitality and mental well-being (SF-36) by employment status and gender

Data basis: GEDA 2010

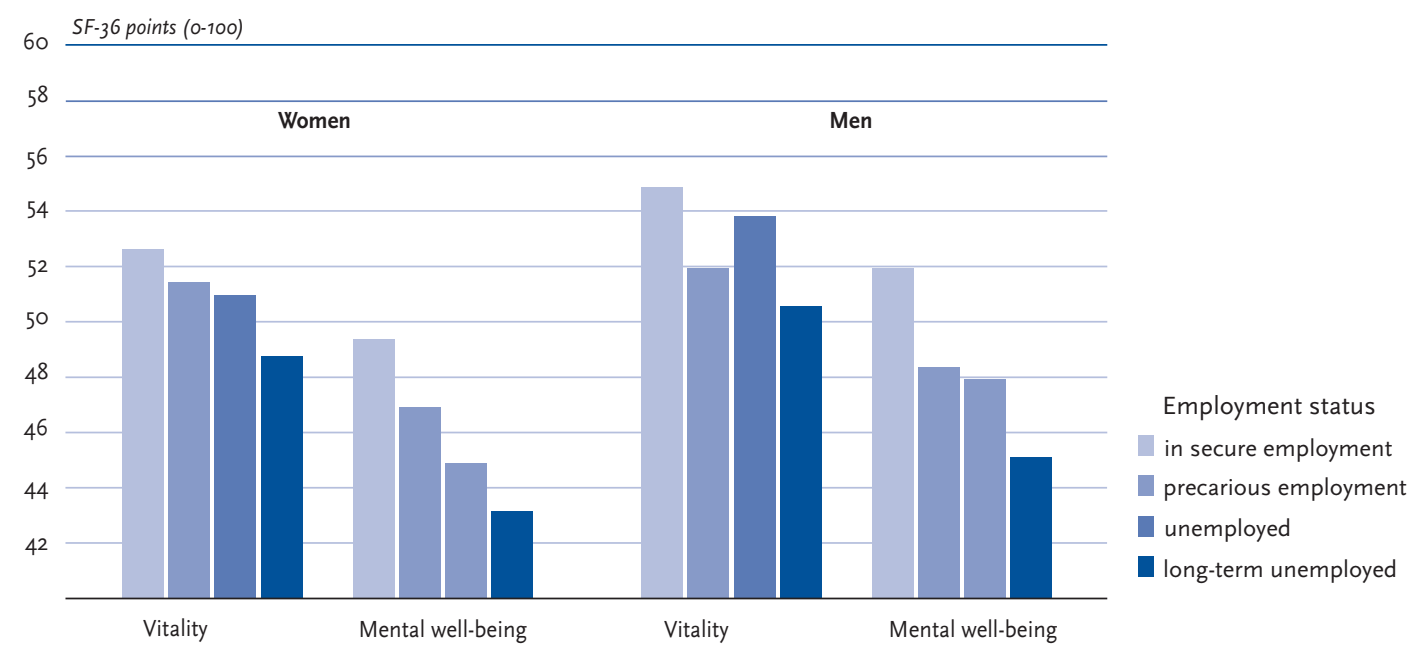

ployed more frequently and find it harder to find a new job (Lange, Lampert 2005, RKI 2003, Thiede, Traub 1997). In the 2010 GEDA study, $15 \%$ of the women and $16 \%$ of the men with experience of unemployment over the previous five years reported that the loss of their job was partly connected to their state of health. At the same time, however, $19 \%$ of the women interviewed and $15 \%$ of the men believed that their state of health had deteriorated as a result of their unemployment.

The 2010 GEDA study makes it possible to compare the connections between a person's current and former experiences of unemployment and their subjective health status. Self-rated health is measured using a five-step scale from »very good « to »bad «. Table 1 shows the risk of a less than »good « self-rated health status in relation to the experience of unemployment in the last 5 years. We controlled for age differences among respondents. In line with comparable analyses based on the 1998 National Health Survey, the results suggest that current unemployment in particular has a negative impact on health (RKI 2003, Thiede, Traub 1997).

Past experiences also still have an effect on those who are currently employed, although this influence is smaller than the effect of current unemployment. Additionally, employed people who have experienced longer episodes of unemployment before are more at risk of assessing their own health status as less than "good « than those who had only little experience with unemployment. However, the

Figure 5

Percentage of smokers and heavy smokers by employment status and gender Data basis: GEDA 2010

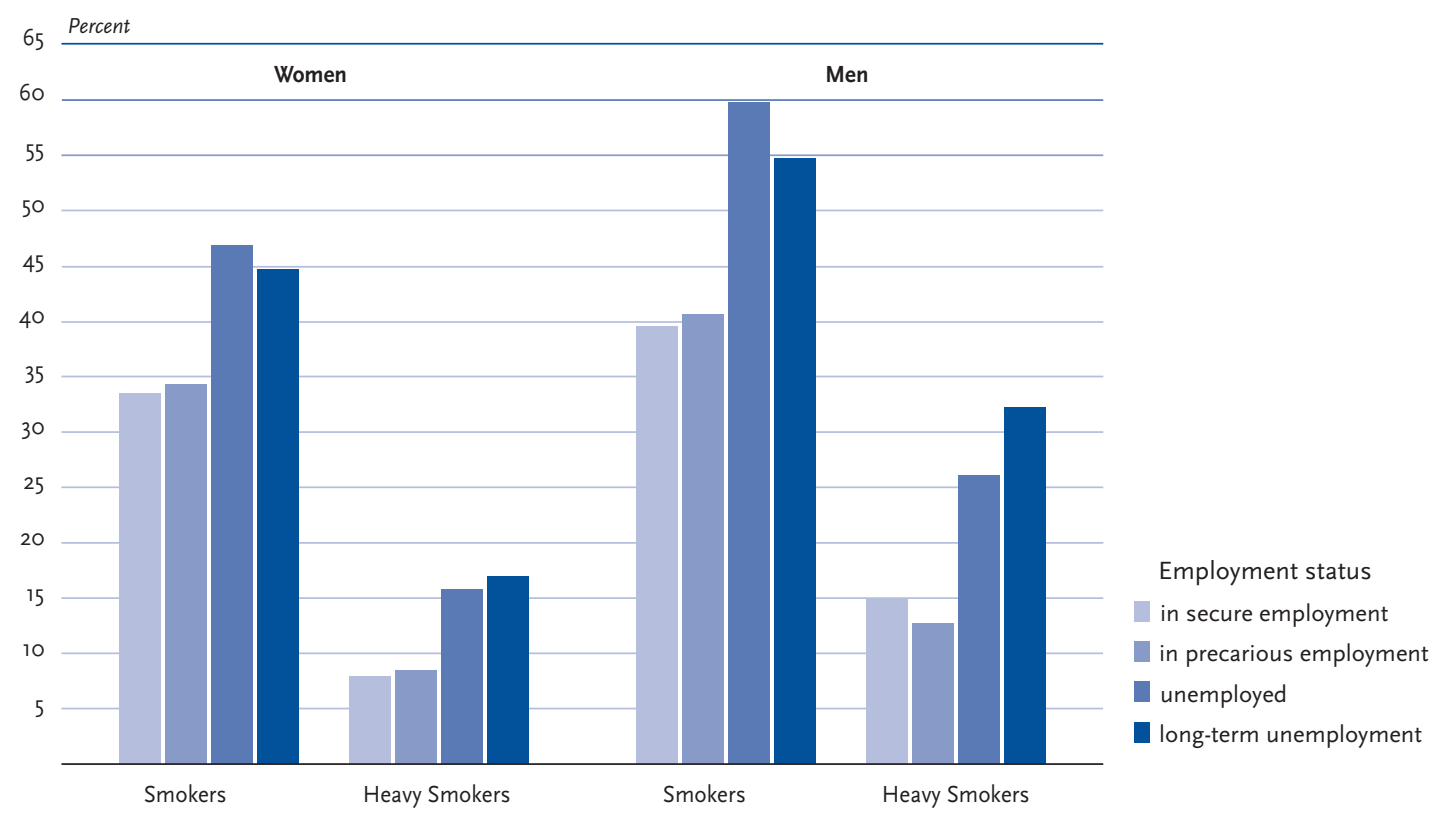


Table 1

Risk of assessing one's health as satisfactory or worse by experience of unemployment, employment status and gender

Datenbasis: GEDA 2010

\begin{tabular}{|c|c|c|c|}
\hline & & Women & Men \\
\hline $\begin{array}{l}\text { Current } \\
\text { employment status }\end{array}$ & $\begin{array}{r}\text { Experience of } \\
\text { unemployment }\end{array}$ & $\begin{array}{r}\text { OR } \\
(95 \%-\mathrm{CI}) \\
\end{array}$ & $\begin{array}{r}\text { OR } \\
(95 \%-\mathrm{Cl}) \\
\end{array}$ \\
\hline \multirow[t]{4}{*}{ employed } & none & Ref. & Ref \\
\hline & 1 to 5 month & $\begin{array}{r}0.83 \\
(0.58-1.18) \\
\end{array}$ & $\begin{array}{r}1.24 \\
(0.94-1.65)\end{array}$ \\
\hline & 6 to 11 month & $\begin{array}{r}1.28 \\
(0.87-1.87) \\
\end{array}$ & $\begin{array}{r}1.11 \\
(0.79-1.54) \\
\end{array}$ \\
\hline & 1 year and more & $\begin{array}{r}1.98 \% \\
(1.43-2.75) \\
\end{array}$ & $\begin{array}{r}1.70 \\
(1.32-2.19) \\
\end{array}$ \\
\hline \multirow[t]{4}{*}{ unemployed } & none & $\begin{array}{r}5.13 * \\
(2.56-10.24)\end{array}$ & $\begin{array}{r}2.23 \\
(1.28-3.87) \\
\end{array}$ \\
\hline & 1 to 5 month & $\begin{array}{r}2.82 \% \\
(1.55-5.13) \\
\end{array}$ & $\begin{array}{r}2.56 \\
(1.41-4.64)\end{array}$ \\
\hline & 6 to 11 month & $\begin{array}{r}3.51^{*} \\
(1.96-6.30) \\
\end{array}$ & $\begin{array}{r}1.97 * \\
(1.18-3.31) \\
\end{array}$ \\
\hline & 1 year and more & $\begin{array}{r}5.96 * \\
(4.42-8.03)\end{array}$ & $\begin{array}{r}3.40 \\
(2.67-4.34)\end{array}$ \\
\hline
\end{tabular}

$*_{\mathrm{p}}<0.05$

risk of employed with experiences of unemployment is lower than the risk of men and women who are currently unemployed, even if the latter have no previous experiences with unemployment.

\section{Discussion}

The findings indicate a stable relation between unemployment, precarious employment and health in Germany. The risk of mortality is higher among unemployed people, they have more mental illnesses and complaints, and they behave more often in a way that puts their health at risk. Current evidence for Germany leads to the conclusion that there is a causal relationship between an experience of unemployment and job insecurity on the one hand, and a deterioration of mental health on the other. Furthermore, health problems frequently also lead to unemployment. Therefore, the direct effects of unemployment on health are therefore overestimated if it is not taken into account, that diseases are a major cause of unemployment.

The findings on the extent of health differences between unemployed and employed people on the basis of the 2010 GEDA study are comparable with results from other data sources such as the micro-census of official statistics or the data of the statutory health insurance companies (Gross 2006, Hollederer 2011). All in all, it is shown that the unemployed generally have a poorer state of health than the employed, that this difference is partly due to the life situation of the unemployed, and that it is less pronounced among women than among men.

International comparative studies have also come to the conclusion that unemployment and health are closely associated in most European countries (Bambra, Eikemo 2009,
Bartley 1994). Analyses based on the 2004 European Social Survey suggested that unemployed women and men had a worse health status than employed people of the same age in all 23 participating countries. Comparisons of the various welfare regimes showed that the differences between the countries were relatively minor.

Initial findings on the development of health inequalities as a function of employment status are available for Germany (Kroll 2010, Kroll, Lampert 2011 b). In the context of a disproportionately higher risk of poverty among the unemployed compared to the population average (Frick, Grabka 2008, Goebel, Richter 2007), health inequalities between unemployed and employed men have widened over the past two decades in Germany. In the case of women, by contrast, they have remained largely stable.

In view of the often documented connections with health, unemployment and precarious employment should remain prominently on the agenda of the health sciences and health policy - also in times when unemployment rates are declining. In the fields of prevention, health promotion and also medical interventions, the results presented illustrate once more the need to take steps to combat both the health-related consequences and the health-related causes of unemployment. To this purpose, it will be essential both for the social partners in the economy and for the stakeholders in healthcare to take effective and long-term measures (Morfeld et al. 2005).

Dr. Lars Eric Kroll, Dr. Thomas Lampert Robert Koch Institute Department of Epidemiology and Health Reporting 


\section{Bibliography}

Arrow JO (1996) Estimating the influence of health as a risk factor on unemployment: A survival analysis of employment durations for workers surveyed in the German Socio-Economic Panel (19841990). Soc Sci Med 42(12): 1651-1659

Bambra C, Eikemo TA (2009) Welfare state regimes, unemployment and health: a comparative study of the relationship between unemployment and self-reported health in 23 European countries. J Epidemiol Community Health 63(2): 92-98

Bartley M (1994) Unemployment and ill health: understanding the relationship. J Epidemiol Community Health 48(4): 333-337

BBR - Bundesamt für Bauwesen und Raumordnung (2010) INKAR 2010 - Indikatoren, Karten und Graphiken zur Raum- und Stadtentwicklung in Deutschland und in Europa. Bundesinstitut für Bau-, Stadt- und Raumforschung, Wiesbaden

Bellach BM, Ellert U, Radoschewski M (2000) Der SF-36 im BundesGesundheitssurvey. Erste Ergebnisse und neue Fragen. Bundesgesundheitsbl-Gesundheitsforsch-Gesundheitsschutz 43(3): 210-216

Berth H, Förster P, Balck F et al. (2008) Arbeitslosigkeitserfahrungen, Arbeitsplatzunsicherheit und der Bedarf an psychosozialer Versorgung. Gesundheitswesen 70: 289-294

Bispinck R, Schulten T (2011) Trade Union Responses to Precarious Employment in Germany. WSI-Diskussionspapier 178

Brenner H (2006) Arbeitslosigkeit. In: Stoppe G, Bramesfeld A, Schwartz F-W (Hrsg) Volkskrankheit Depression? Springer, Berlin, $\mathrm{S}_{16}{ }_{3}-189$

Brief AP, Konovsky MA, Goodwin R et al. (1995) Inferring the meaning of work from the effects of unemployment. J Appl Soc Psychol 25(8): 693-711

Bullinger M (1995) German translation and psychometric testing of the SF-36 Health Survey: preliminary results from the IQOLA Project. International Quality of Life Assessment. Soc Sci Med 41(10): 1359-1366

Creed PA, Macintyre SR (2001) The relative effects of deprivation of the latent and manifest benefits of employment on the well-being of unemployed people. J Occup Health Psychol 6(4): 324-331

Dragano N, Siegrist J (2006) Arbeitsbedingter Stress als Folge von betrieblichen Rationalisierungsprozessen - die gesundheitlichen Konsequenzen. In: Badura B, Schnellschmidt H, Vetter C (Hrsg) Fehlzeitenreport 2005. Springer, Heidelberg, S 167-182

Elkeles T (1999) Arbeitslosigkeit, Langzeitarbeitslosigkeit und Gesundheit. Sozialer Fortschritt 6: 150-155

Ferrie JE (2006) Gesundheitliche Folgen der Arbeitsplatzunsicherheit. In: Badura B, Schnellschmidt H, Vetter C (Hrsg) Fehlzeiten-Report 2005. Springer, Berlin

Frick JR, Grabka M (2008) Niedrigere Arbeitslosigkeit sorgt für weniger Armutsrisiko und Ungleichheit. DIW Wochenbericht 75(38): $556-566$

Fryer JP (1986) Employment deprivation and personal agency during unemployment: A critical discussion of Jahoda's Explanation of the psychological effects. Social Behaviour 1(1): 3-23

Goebel J, Richter M (2007) Nach der Einführung von Arbeitslosengeld II: Deutlich mehr Verlierer als Gewinner unter den Hilfeempfängern. DIW Wochenbericht 2007 (50): 753-761

Grobe TG (2006) Sterben Arbeitslose früher? In: Hollederer A, Brand H (Hrsg) Arbeitslosigkeit, Gesundheit und Krankheit, Huber Bern
Hanisch KA (1999) Job Loss and Unemployment Research from 1994 to 1998: A Review and Recommendations for Research and Intervention. J Vocat Behav 55(2): 188-220

Hollederer A (2003) Arbeitslos - Gesundheit los - chancenlos? IAB Kurzbericht 4

Hollederer A (2011) Unemployment and health in the German population: results from a 2005 microcensus. J Public Health 19(3): 257-268

Jahoda M (1983) Wieviel Arbeit braucht der Mensch. Beltz Verlag, Weinheim

Janlert U, Hammarstrom A (2009) Which theory is best? Explanatory models of the relationship between unemployment and health. BMC Public Health 9(1): 235

Kroll LE (2010) Sozialer Wandel, soziale Ungleichheit und Gesundheit. Die Entwicklung sozialer und gesundheitlicher Ungleichheiten in Deutschland zwischen 1984 und 2006. VS Verlag, Wiesbaden

Kroll LE, Lampert T (2011 a) Unemployment, social support and health problems: results of the GEDA study in Germany, 2009. Dtsch Arztebl Int 108(4): 47-52

http://www.aerzteblatt.de/int (last revised: 08.03.2012)

Kroll LE, Lampert T (2011 b) Changing health inequalities in Germany from 1994 to 2008 between employed and unemployed adults. Int J Public Health 56(3): 329-339

Kurth BM, Lange C, Kamtsiuris P et al. (2009) Gesundheitsmonitoring am Robert Koch-Institut. Bundesgesundheitsbl-Gesundheitsforsch-Gesundheitsschutz 52(5): 557-570

Lampert T, Kroll LE, Kuntz B et al. (2011) Gesundheitliche Ungleichheit. In: Destatis, WZB (Hrsg) Datenreport 2011: Der Sozialbericht für Deutschland. Bundeszentrale für politische Bildung, Wiesbaden, S 247-258

Lange C, Lampert T (2005) Die Gesundheit arbeitsloser Frauen und Männer. Bundesgesundheitsbl-Gesundheitsforsch-Gesundheitsschutz 48(11): 1256-1264

Martikainen PT, Valkonen T (1996) Excess mortality of unemployed men and women during a period of rapidly increasing unemployment. The Lancet 348(9032): 909-912

Morfeld M, Bullinger M, Nantke J et al. (2005) The version 2.0 of the SF-36 Health Survey: results of a population-representative study. Sozial- und Präventivmedizin 50(5): 292-300

Novo M, Hammarstrom A, Janlert U (2001) Do high levels of unemployment influence the health of those who are not unemployed? A gendered comparison of young men and women during boom and recession. Soc Sci Med 53(3): 293-303

RKI - Robert Koch-Institut (2003) Arbeitslosigkeit und Gesundheit. Gesundheitsberichterstattung des Bundes. Heft 13. RKI, Berlin http://www.rki.de (last revised: 08.03.2012)

Scanlan JN, Bundy AC (2009) Is the health of young unemployed Australians worse in times of low unemployment? Aust NZ J Public Health 33(1): 79-82

Schunck R, Rogge B (2010) Unemployment and its association with health-relevant actions: investigating the role of time perspective with German census data. Int J Public Health 55(4): 271-278

Thiede M, Traub S (1997) Mutual influences of health and poverty. Evidence from German panel data. Soc Sci Med 45(6): 867-877 
Voss M, Nylén L, Floderus B et al. (2004) Unemployment and early cause-specific mortality: A study based on the Swedish twin registry. Am J Public Health 94(12): 2155-2161

Warr P (1987) Work, Unemployment and Mental Health. Oxford University Press, Oxford

Weber A, Hörmann G, Heipertz W (2007) Arbeitslosigkeit und Gesundheit aus sozialmedizinischer Sicht. Dtsch Ärztebl 104(43): 2957-2962

Zok K (2006) Personalabbau, Arbeitsplatzunsicherheit und Gesundheit - Ergebnisse einer repräsentativen Umfrage. In: Badura B, Schnellschmidt H, Vetter C (Hrsg) Fehlzeitenreport 2005. Springer, Heidelberg, S 147-166 
GBE kompakt

Published by Robert Koch-Institut Nordufer 20 13353 Berlin

Editorial staff Martina Rabenberg, Dr. Livia Ryl

Robert Koch Institute Department of Epidemiology and

Health Reporting General-Pape-Straße 62 12101 Berlin Tel.: 030-18 754-3400

E-Mail: gbe@rki.de www.rki.de/gbe

How to quote the title Kroll LE, Lampert T (2012) Unemployment, precarious work and health. Published by Robert Koch Institute Berlin.

GBE kompakt 3(1) www.rki.de/gbe-kompakt (last revised: o8.03.2012)

ISSN 2191-4974

The Robert Koch Institute is a federal institute within the portfolio of the Federal Ministry of Health 